\title{
PENERAPAN APLIKASI MATHEMATICS MOVIE TERHADAP MINAT BELAJAR MATEMATIKA DAN KEMAMPUAN ANALOGI RESPONDEN
}

\author{
Oleh: \\ Saluky* \\ *Dosen Jurusan Tadris Matematika FITK IAIN Syekh Nurjati Cirebon \\ Email:saluky@syekhnurjati.ac.id
}

\begin{abstract}
ABSTRAK
Mathematics is a field of study that has an important role to measure the ability of the student. Poor understanding of students in schools on the subject matter of mathematics due to lack of interest in studying mathematics and cognitive abilities of students in schools is not up to the ability to maximize the existing analogy to students. Student interest in learning mathematics is less than optimal, it is necessary to develop the ability to maximize student interest in learning math analogy. one way to increase student analogy using Media. Mathematical Movie is instructional media delivered by teachers in the classroom with multimedia. Media movie mathematics useful in mathematics, as in mathematics definitely need a medium of learning.

Math media can increase the interest and ability to learn mathematics student analogy. The ability of this analogy is very important in the learning of mathematics, such as mathematics should involve penganalogian. This research is a quantitative research using experimental methods. The technique of collecting data using questionnaires and tests Multiple choice. Data analysis technique used is the correlation analysis, regression analysis and path analysis.

Data analysis started with the analysis of figures obtained correlation correlation between the influence of interest in learning math mathematics magnitude movies 0.574 with a degree of relationship, the effects on the ability analogy films mathematics to 0.454 students with the level of relationships, and interest in learning mathematical. The calculation result of research using path analysis we concluded that there is a direct effect of the application of mathematics to the interests of the film in learning mathematics by $73 \%$, the application of mathematics to the ability of the film analogy students $60.6 \%$ and interest in learning math analogy with the student's ability by $75 \%$ So that with the application of mathematical applications for the movie analogies can increase the interest and ability of the students in learning mathematics learning.
\end{abstract}

Keywords: Movie Mathematics, Learning Interests, Ability Analogy 


\section{A. PENDAHULUAN}

Pendidikan merupakan media yang sangat berperan untuk menciptakan manusia yang berkualitas dan berpotensi dalam arti yang seluas-luasnya. Melalui pendidikan akan terjadi proses pendewasaan diri sehingga di dalam proses pengambilan keputusan terhadap suatu masalah yang dihadapi selalu disertai dengan rasa tanggung jawab yang besar.

Pelajaran Matematika merupakan salah satu bidang studi yang memiliki peranan penting dalam dunia pendidikan. Hal ini dapat dilihat dari alokasi waktu pelajaran di sekolah lebih banyak dibandingkan dengan mata pelajaran yang lain. Bagaimana cara seorang guru meyakinkan responden bahwa pelajaran matematika tidak sulit seperti yang mereka bayangkan karena kesenangan mereka tersebut dapat mempengaruhi hasil belajar responden. Matematika adalah bahasa universal untuk menyajikan gagasan atau pengetahuan secara formal dan presisi sehingga tidak memungkinkan terjadinya multi tafsir.Penyampaiannya adalah dengan membawa gagasan dan pengetahuan konkret ke bentuk abstrak melalui pendefinisian variabel dan parameter sesuai dengan yang ingin disajikan. Penyajian dalam bentuk abstrak melalui matematika akan mempermudah analisis dan evaluasi selanjutnya.

Kendala bagi dunia pendidikan untuk menghasilkan lulusan yang berkualitas adalah masih banyaknya sekolah yang mempunyai pola pikir tradisional di dalam menjalankan proses belajarnya yaitu sekolah hanya menekankan pada kemampuan logika (matematika) dan bahasa. Suatu kekeliruan yang besar jika setiap kenaikan kelas, prestasi anak didik hanya diukur dari kemampuan matematika dan bahasa.Dengan demikian sistem pendidikan nasional yang mengukur tingkat kecerdasan anak didik yang sematamata hanya menekankan kemampuan logika dan bahasa perlu direvisi.Kecerdasan intelektual tidak hanya mencakup dua parameter tersebut, di atas tetapi juga harus dilihat dari aspek kinetis, musical, visual-spatial, interpersonal, intrapersonal, dan naturalis.Jenis-jenis kecerdasan intelektual tersebut dikenal dengan sebutan kecerdasan jamak (Multiple Intelligences). 
Dengan media yang menarik materi pelajaran akan mudah diserap oleh responden, karena dengan menggunakan media dapat mempermudah pemahaman belajar anak dalam pencapaian tujuan pengajaran. Pembelajaran matematika dibeberapa tempat belum sesuai dengan yang diharapkan. Hal ini disebabkan oleh: 1). Kurangnya keterampilan guru dalam memilih media yang tepat dalam pembelajaran, 2). Kurangnya keterampilan guru untuk memanfaatkan media, 3). Minat belajar responden kurang atau belum sesuai dengan apa yang diharapkan. Untuk itu diperlukan alat atau media yang dapat menarik minat responden, tetapi ternyata guru dalam melaksanakan pembelajaran kebanyakan masih bersifat konvensional, artinya guru masih mendominasi jalannya pembelajaran dan belum memanfaatkan media pembelajaran secara maksimal sehingga pembelajaran yang dilakukan cenderung kurang menarik responden.Selain itu guru belum sepenuhnya memanfaatkan alat peraga dalam pembelajaran matematika.Kebanyakan masih menggunakan alat peraga lembar kerja yang dibeli dari penerbit yang belum sesuai dengan kebutuhan responden.Untuk mengatasi hal itu maka menggunakan media pembelajaran yang mudah dan sederhana yang mudah dipahami responden yaitu melalui media audio visual.

Media pembelajaran yang dimaksudkan dalam penelitian ini adalah media mathematics movie yang digunakan untuk menunjang proses belajar mengajar khususnya pada mata pelajaran matematika terutama pada materi tentang bangun ruang. Dengan memperbaiki proses pembelajaran dengan memanfaatkan penggunaan media mathematics movie yang mudah didapat. Diharapkan dengan menggunakan media mathematics movie lebih mewarnai proses pembelajaran agar pembelajaran lebih bermakna, materi mudah dipahami responden, bergairah serta bernuansa PAKEM (Aktif, Kreatif, Efektif dan Menyenangkan). Disisi lain responden pun akhirnya akan lebih akrab dan lebih berminat belajar matematika. Dan minat belajar responden meningkat.

Dari pemahaman yang telah diuraikan tersebut, betapa pentingnya minat tersebut dalam kehidupan,terutama dalan belajar.Oleh karena itu akan diteliti Apakah Terdapat Pengaruh Penerapan Mathematics Movie Terhadap Minat Belajar Matematika Dan Kemampuan Analogi Responden. 


\section{B. PEMBAHASAN}

\section{Pengertian Media Pembelajaran Mathematics Movie}

Kata media berasal dari bahasa Latin medius yang secara harfiah berarti "tengah", "perantara" atau "pengantar" (Arsyad, 2003: 3). Media merupakan sesuatu yang bersifat menyalurkan pesan dan dapat merangsang pikiran, perasaan, dan kemauan audien (responden) sehingga dapat mendorong terjadinya proses belajar pada dirinya. Penggunaan media secara secara kreatif akan memungkinkan audien (responden) untuk belajar lebih baik dan dapat meningkatkan performan mereka sesuai dengan tujuan yang ingin dicapai (Usman dan Asnawir, 2002: 11). Briggs menyatakan bahwa media adalah segala bentuk fisik yang dapat menyampaikan pesan serta merangsang peserta didik untuk belajar.Media yang dimaksud adalah, guru, buku dan lingkungan sekolah (Hamzah, 2011: 114).Media menurut Zain (1997: 136) secara bahasa memiliki arti perantara atau pengantar pesan. Sedangkan menurut Gagne sebagaimana yang dikutip oleh Sadiman (2005: 6) dalam bukunya "Media Pendidikan: Pengembangan dan Pemanfaatannya" media adalah berbagai jenis komponen dalam lingkungan responden yang dapat merangsangnya untuk belajar.

Media pembelajaran, menurut Kemp dan Dayton dalam bukunya Azhar Arsyad (2002: 9) menyatakan bahwa " Media pembelajaran dapat memnuhi tiga fungsi utama apabila media itu digunakan untuk perorangan, kelompok, atau kelompok pendengar yang besar jumlahnya, yaitu: (1) Memotivasi minat atau tindakan (2) Menyampikan informasi (3) Memberi instruksi.

Menurut Kemp \& Dayton, sebagaimana dikutip oleh A. Arsyad (2003: 22) dalam bukunya "Media Pembelajaran" menyatakan, bahwa media mempunyai manfaat, yaitu sebagai berikut : 1. Penyampaian pelajaran menjadi lebih baku. Setiap pelajar yang melihat atau mendengar penyaji melalui media menerima pesan yang sama. 2. Pengajaran bisa lebih menarik. Media dapat diasosiasikan sebagai penarik perhatian dan membuat responden tetap terjaga dan memperhatikan. 3. Pembelajaran menjadi lebih interaktif. 4. Lama waktu pengajaran yang diperlukan dapat dipersingkat. 5. Kualitas hasil belajar dapat ditingkatkan. 6. Pengajaran dapat diberikan kapan dan dimana diinginkan atau 
diperlukan. 7. Sikap positif responden terhadap apa yang mereka pelajari dan terhadap proses belajar dapat ditingkatkan 8. Peran guru dapat berubah ke arah yang lebih positif.Beban guru untuk penjelasan yang berulang-ulang mengenai isi pelajaran dapat dikurangi bahkan dihilangkan.

Menurut Arief Sadiman dalam bukunya, Media Pendidikan (2009:6-7), kata media berasal dari bahasa latin dan merupakan bentuk jamak dari kata medium yang secara harfiah berarti perantara atau pengantar. Medoe adalah perantara atau pengantar pesan dari pengirim ke penerima pesan.Media pembelajaran adalah media yang membawa pesan-pesan atau informasi yang bertujuan intruksional atau mengandung maksud-maksud pengajaran. Media pembelajaran bisa dikatakan sebagai alat yang bisa merangsang responden untuk terjadinya proses belajar (Hamdani, 2011: 243-244). Berdasarkan pendapat di atas, media pembelajaran adalah alat yang bisa membawa pesan, mengandung maksud-maksud pengajaran sehingga dapat merangsang responden untuk terjadinya proses belajar.

Media pembelajaran dalam proses belajar mengajar dapat membangkitkan keinginan dan minat yang baru, membangkitkan motivasi dan rangsangan kegiatan belajar, bahkan membawa pengaruh-pengaruh psikologi terhadap responden (Hamdani, 2011: 244). Adanya media pembelajaran responden lebih tertarik untuk lebih giat lagi dalam kegiatan belajar mengajar, selain itu responden juga mendapatkan pembaharuan dengan adanya media pembelajaran.

Pengertian matematika sendiri (Basyiruddin Usman, 2002: 9) adalah bahasa simbolis yang memiliki fungsi praktis untuk mengekspresikan hubungan kuantitatif dan keruangan dalam cabang ilmu pengetahuan eksak, tentang bilangan, kalkulasi, penalaran logik, dan bentuk aturan-aturan yang kuat dan jelas, dan prosedur operasional yang digunakan dalam penyelesaian masalah mengenai bilangan. Sedangkan pengertian movie (film) (Suyitno, 2001: 1) adalah bahwa movie merupakan gambar hidup dengan cerita yang sangat menarik dan dapat diulangulang baik teori maupun praktek, dan dunia luar dapat dibawa ke dalam kelas, dan untuk mengatasi keterbatasan indera penglihatan, serta merangsang motivasi kegiatan anak yang dapat memperjelas proses pembelajaran sehingga 
minat belajar dapat meningkat. Dari kedua pengertian tersebut, penulis menyimpulkan bahwa mathematics movie adalah suatu pembelajaran matematika yang praktis untuk responden dengan menggunakan media film atau gambar hidup dengan cerita yang menarik, yang akan menjadi motivasi bagi responden agar dapat meningkatkan minat belajar matematika. Mathematics movie kurang efektif jika diberikan tersendiri, karena itu harus digunakan dengan metode lain setelah penayangan movie selesai. Movie berperan sebagai penarik perhatian yang bersifat menghibur.

\section{Minat Belajar Matematika}

Minat (Tim Prima Pena, 2004: 532) secara bahasa diartikan sebagai keinginan yang kuat, gairah, kesukaan (kecenderungan hati) kepada sesuatu.Sedangkan secara istilah minat (Muhibbin Syah, 2005: 151) adalah kecenderungan dan kegairahan yang tinggi atau keinginan yang besar terhadap sesuatu. Sedangkan pengertian minat secara istilah telah banyak dikemukakan oleh para ahli, di antaranya yang dikemukakan oleh Hilgard yang dikutip oleh Slameto (1991: 57) menyatakan "Interest is persisting tendency to pay attention to end enjoy some activity and content". Menurut Slameto (1991: 180) minat adalah suatu rasa lebih suka dan rasa keterikatan pada suatu hal atau aktivitas tanpa ada yang menyuruh. Minat pada dasarnya adalah penerimaan akan suatu hubungan antara diri sendiri dengan sesuatu di luar diri. Semakin kuat atau dekat hubungan tersebut, semakin besar minat. Sardiman A. M. (1988: 76) berpendapat bahwa "minat diartikan sebagai suatu kondisi yang terjadi apabila seseorang melihat ciriciri atau arti sementara situasi yang dihubungkan dengan keinginan-keinginan atau kebutuhankebutuhannya sendiri." Dalam hal ini Simanjuntak (1983: 52) berpendapat bahwa "Minat merupakan suatu motif yang menyebabkan individu berhubungan secara aktif dengan sesuatu yang menarik".

Minat belajar matematika tidak timbul begitu saja secara tiba-tiba, ada beberapa faktor yang mengakibatkan minat belajar matematika itu muncul dari dalam diri responden diantaranya yaitu faktor internal dan faktor eksternal.Faktor internal adalah faktor yang membuat responden berminat pada matematika, ditimbulkan dari dalam diri responden. Bila responden menyadari bahwa belajar 
merupakan suatu alat untuk mencapai beberapa tujuan yang dianggapnya penting, dan bila responden melihat bahwa hasil dari pengalaman belajarnya akan membawa kemajuan pada dirinya, kemungkinan besar ia akan berminat (bermotivasi) untuk mempelajarinya (Slameto, 2010: 180). Faktor eksternal adalah faktor dari luar diri responden yang menimbulkan minat belajar matematika.Faktor eksternal misalnya saja dorongan dari orang-orang terdekat seperti keluarga, guru, teman, bahkan tersedianya sarana dan prasarana atau fasilitas dan keadaan lingkungan dapat mempengaruhi minat belajar matematika responden.

\section{Kemampuan Analogi}

Menurut Kamus Besar Bahasa Indonesia (KBBI) (1993: 36), analogi adalah persamaan atau persesuaian antara dua benda atau hal yang berlainan kias atau kesepadanan antara bentuk bahasa yang menjadi dasar terjadinya bentuk lain. Menurut Kariadinata (2010: 21), analogi adalah kemampuan menarik berdasarkan keserupaan dua kasus. Menurut Lorens Bagus dalam skripsi Dapiah (2004: 20), analogi berasal dari bahasa Yunani yakni terdiri dari dua kata ana artinya menurut dan logos artinya rasio, proporsi, perbandingan, sedangkan menurut Wagiman ( 2009: 38), analogi dalam bahasa yunani adalah analogos yang berarti kemiripan, analogi berbasiskan pada adanya kemiripan.

Menurut Soekadijo (1999: 139) analogi adalah berbicara tentang dua hal yang berlainan, yang satu bukan yang lain, tetapi dua hal yang berbeda itu dibandingkan satu dengan yang lain. Dalam analogi yang dicari adalah keserupaan dari dua hal yang berbeda, dan menarik kesimpulan atas dasar keserupaan itu.Dengan demikian analogi dapat dimanfaatkan sebagai penjelas atau sebagai dasar penalaran. Menurut Wagiman (2009: 40), analogi menandakan hubungan umum antara dua hal atau lebih, jika menandakan kesamaan dari dua bagian. Istilah yunani yang muncul 32 kemudian berarti kesamaan-kesamaan dalam konseo-konsep atu istilah-istilah.Oleh karena itu, istilah ini merupakan "konsep yang menunjukkan kesamaan atau keserupaan antara hal-hal dan bentuk kesimpulan berdasarkan penegas kesamaankesamaan antara dua hal".Menurut Deristadt dan Riegeluth dalam Riyanto (2010: 26) menyatakan bahwa analogi 
merupakan komponen strategi teori elaborasi yang sangat penting, karena dapat memudahkan pemahaman terhadap pengetahuan baru dengan membandingkan pengetahuan yang telah dikenal.

Dengan demikian makin dekat persamaan antara pengetahuan baru dengan pengetahuan yang dijadikan analogi, maka makin efektif analogi itu.Dari seri logika, menurut Dapiah (2004: 34) analogi merupakan suatu relasi persamaan antara dua atau lebih pernyataan yang memungkinkan ditariknya kesimpulan dengan bergantung pada jenis relasi yang bersangkutan.Umumnya dengan menemukan persamaan-persamaan dalam beberapa aspek.

Kemampuan bisa disebut dengan suati hal yang lebih pada diri seseorang mengenai suatu pekerjaan. Hal ini sebagaimana pendapat Spencer and Spencer yang mendefinisikan kemampuan sebagai karakteristik yang menonjol dari seseorang individu yang berhubungan dengan kinerja efektif dan atau superior dalam suatu pekerjaan atau situasi ( Hamzah B Uno, 2008: 129). Kemampuan adalah kesanggupan, kecakapan, dan kekuatan yang didapatkan melalui latihan dalam melaksanakan suatu pekerjaan. Menurut Soekadijo (1999: 139) analogi adalah berbicara tentang dua hal yang berlainan, yang satu bukan yang lain, tetapi dua hal yang berbeda itu dibandingkan satu dengan yang lain. Dalam analogi yang dicari adalah keserupaan dari dua hal yang berbeda, dan menarik kesimpulan atas dasar keserupaan itu.Dengan demikian analogi dapat dimanfaatkan sebagai penjelas atau sebagai dasar penalaran.Dengan demikian, penulis menyimpulkan bahwa kemampuan analogi adalah kecakapan seseorang dalam mencari keserupaan suatu pola atau konsep melalui latihan-latihan yang mengukur aspek kognitif responden.

\section{Hubungan Mathematics Movie dengan Minat Belajar Matematika dan Kemampuan Analogi Responden}

Seorang responden dalam melakukan aktivitas belajar memerlukan adanya dorongan tertentu agar responden tersebut memiliki ketertarikan dalam dirinya dalam belajar matematika.Untuk dapat meningkatan minat belajar responden yang maksimal, tentunya perlu diperhatikan berbagai faktor yang dapat membangkitkan para responden untuk belajar dengan efektif.Keadaan yang menyenangkan baik 
dari segi penyajian materi ataupun dari segi performan guru yang memberikan materi pelajaran dan soalsoal kepada responden saat belajar merupakan salah satu kondisi psikis yang dapat mendorong munculnya minat belajar responden.Kegiatan responden dalam belajar selalu dipengaruhi oleh faktor internal yaitu kesehatan mental yang dialami oleh individu tersebut.Responden yang mendapat penularan emosi dengan memberikan motivasi yang kuat akan menimbulkan semangat, sebaliknya jika mendapat kecaman atau selalu disalahkan terus-menerus, maka akan melemahkan semangat.

Ada banyak cara untuk meningkatkan kemampuan analogi, salah satu cara yang dipandang tepat adalah terus melatih cara berfikir abstrak responden. Berfikir abstrak memungkinkan responden berlatih untuk mengekspresikan pemahaman, memverbalkan proses berfikir, dan mengklarifikasikan pemahaman. Dalam berfikir abstrak perlu diperhatikan beberapa hal, penganalogian yang tepat yang memungkinkan responden dapat mengekspresikan kemampuan matematikanya dengan baik.Selain itu perlu dirancang pula peran guru dalam mengarahkan daya nalar para responden.Pernyataan di atas dapat disimpulkan bahwa mathematics movie sangat erat hubungannya dengan minat belajar dan kemampuan analogi responden apalagi khususnya dalam mata pelajaran matematika.

Dengan adanya pengaruh mathematics movie maka responden mampu atau dapat mengoptimalkan kemampuannya termasuk ketertarikan atau minatnya pada mata pelajaran khususnya pada pelajaran matematika yang dianggap mereka itu susah dan menakutkan, mereka akan menjadi senang dengan adanya peran mathematics movie. Kecenderungan minat belajar respondenakan selalu dipengaruhi beberapa faktor yang akan menunjukkan responden tersebut suka atau tidak suka terhadap pelajaran tertentu, sehingga dalam pengajaran mata pelajaran guru harus dapat menghilangkan faktor-faktor negatif yang dapat menurunkan minat responden. salah satunya adalah dengan menciptakan cara pengajaran yang baru seperti mathematics movie. Dengan demikian penerapan mathematics movie diharapkan dapat menjadikan proses pembelajaran matematika semakin mudah dan dapat mengembangkan kemampuan berfikir 
responden melalui daya nalar analogi yang telah dimiliki masing-masing responden. Dengan adanya keterlibatan responden secara langsung dapat membantu menumbuhkan minat dan kemampuan belajar yang positif terhadap matematika.

\section{Kerangka Berpikir}

Salah satu cara untuk meningkatkan pembelajaran dan kemampuan analogi responden adalah dengan adanya pembelajaran mathematics movie terus melatih kemampuan responden untuk berfikir dengan menggunakan hal-hal yang abstrak serta membiasakan diri untuk menggunakan operasi-operasi dan simbolsimbol untuk menyatakan suatu korelasi antara konsep-konsep matematika. Dalam pembelajaran matematika tentunya memerlukan suatu pembelajaran yang baru yaitu dengan adanya mathematics movie ini dapat membantu proses berjalannya pembelajaran di dalam kelas sehingga responden tidak merasa jenuh. Kemampuan analogi responden juga sangat penting bagi responden karena dalam pembelajaran matematika pasti selalu melibatkan penganalogin atau penalaran sehingga dapat membawa responden pada pemahaman yang mendalam tentang matematika dan dapat mengkonstruksikan sendiri pengetahuan mereka melalui daya analoginya.

Adapun indikator yang dijadikan sebagai alat mengukur seberapa besar keinginan seorang responden dalam proses pembelajaran yaitu dengan minat belajar, minat belajar adalah sesuatu keinginan atau kemauan yang disertai perhatian dan keaktifan yang 38 disengaja yang akhirnya melahirkan rasa senang dalam perubahan tingkah laku, baik berupa pengetahuan, sikap dan keterampilan. Dengan mengoptimalkan belajar dengan mathemaics movie, guru dapat mengali potensi untuk mengembangkan rasa tanggung jawab, kerjasama dalam menyelesaikan masalah, serta membuka peluang untuk menumbuhkan rasa ingin tahu pada setiap permasalahan. Dengan mathemaics movie responden dapat pengalaman yang modern dan dapat kesempatan untuk bertanya dan saling memberi penjelasan terhadap sesama teman dengan cara dan bahasanya yang jelas. Dengan demikian, mathemaics movie akan dapat menyelesaikan masalah. Dari pemikiran tersebut, diharapkan dengan pembelajaran menggunakan 
mathemaics movie, dapat menyelesaikan permasalahan khususnya dalam pembelajaran matematika, sehingga dapat meningkatkan minat belajar respondennya.Mathematics movie tentunya memiliki suatu korelasi peran yang positif terhadap minat belajar matematika dan kemampuan analogi responden. Oleh karena itu, melalui mathematics movie tersebut maka respondenakan dapat meningkatkan minat belajar matematika dan kemampuan analogi responden. Adapun bentuk paradigma peran mathematics movie terhadap minat belajar matematika dan kemampuan analogi responden dalam mata pelajaran matematika adalah:

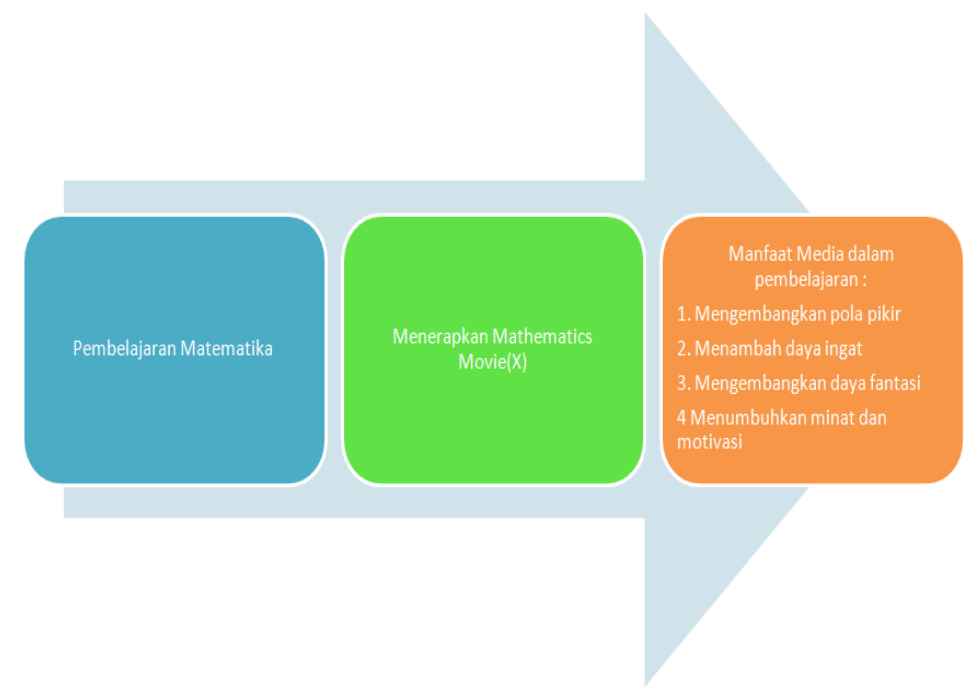

Gambar 1 : Alur Kerangka Berfikir Keterangan : $\mathrm{X}=$ Variabel bebas : Mathematics Movie Y1 = Variabel Terikat : Minat Belajar Matematika Y2 = Variabel Terikat : Kemampuan Analogi Responden

\section{Data Minat belajar dengan Mathematics Movie}

Berdasarkan hasil penelitian dari satu kelas perlakukan yaitu kelas eksperimenyang perlakuannya berupa pembelajaran dengan menggunakan media mathematics movie dengan jumlah responden 35 orang, diperoleh data tes akhir. Untuk mengetahui respon responden terhadap penerapan mathematics movie yang digunakan dalam pembelajaran matematika, peneliti melakukan penyebaran angket yang terdiri dari 25 butir pernyataan yang ditunjukan kepada 35 responden dikelas eksperimen yaitu kelas VIII-H. Dari 25 butir penyataan angket tesebur terdapat 4 dimensi yaitu membuat responden tertarik/ketertarikan, motivasi, 
melatih kemandirian, dan menganalisis tindakan, dan 11 indikator yaitu keseriusan, memperhatikan, mencatat, menyelesaikan tugas dengan sungguhsungguh, berusaha unggul/berperan aktif, kesiapan, mandiri, meneliti, mencari, memeriksa, dan merevisi.

Perhitungan hasil angket dilakukan pada setiap indicator pernyataan yang dikelompokan berdasarkan sub variabel penelitian.

Berikut adalah rekapitulasi persentase hasil angket tentang penerapan penerapan mathematics movie dalam bentuk rata-rata persentase perindikator.Rekapitulasi tersebut dimaksudkan untuk memperoleh interpretasi respon responden secara keseluruhan mengenai penerapan mathematics movie.

Berdasarkan tabel di atas diperoleh respon responden terhadap pembelajaran mtematika dengan menggunakan mathematics movie berkategori baik dengan ratarata prosentase angket sebesar 71,3\%. Besarnya respon responden terhadap pembelajaran matematika yang menggunakan mathematics movie dipengaruhi oleh beberapa faktor, antara lain dapat menambah pengalaman belajar, sesuai dengan pokok bahasan yang diajarkan, dapat memperjelas materi yang diajarkan. Faktor-faktor tersebut yang membuat respon responden terhadap penerapan mathematics movie berada pada kategori baik.

\section{Data Variabel Y1 (Minat Belajar Matematika)}

Untuk mengetahui respon responden terhadap minat belajar matematika, peneliti menggunakan angket sebagai instrument pengumpulan data.Angket tersebut berjumlah 25 item pernyataan.Angket disebarkan kepada 35 responden kelas eksperimen yaitu kelas VIII-H. Angket tersebut menggunakan skala Likert dengan mencantumkan lima pilihan jawaban, yaitu: Sangat Setuju (SS), Setuju (S), Ragu-ragu (RR), Tidak Setuju (TS) dan Sangat Tidak Setuju (STS). Berikut adalah rekapitulasi persentase hasil angket tentang minat belajar matematika dalam bentuk rata-rata persentase perindikator.Rekapitulasi tersebut dimaksudkan untuk memperoleh interpretasi respon responden secara keseluruhan mengenai minat belajar matematika.

Berdasarkan penelitian diperoleh rata-rata minat belajar matematika responden berada pada kategori baik yaitu sebesar 72,6\%. Minat belajar 
matematika responden dipengaruhi oleh beberapa faktor, diantaranya yaitu memiliki perasaan percaya diri, memiliki perasaan senang terhadap pengajar matematika, adanya konsentrasi dalam belajar, adanya apresiasi terhadap pembelajaran matematika, adanya ketangkasan dalam belajar, cara mendengkarkan materi yang disampaikan oleh pengajar yang menyenangkan, adanya hubungan dalam belajar matematika dengan kehidupan sehari-hari, karena faktor-faktor tersebut membuat minat responden dalam belajar matematika menjadi baik/tinggi.

\section{Data Variabel Y2 (Kemampuan Analogi Responden)}

Data ini diperoleh dari hasil tes yang diberikan kepada 35 responden kelas eksperimen.Nilai untuk setiap jawaban yang benar adalah 1, sedangkan nilai untuk jawaban yang salah adalah 0.Untuk lebih detailnya, berikut ini adalah prosentase hasil tes responden tentang kemampuan analogi responden berdasarkan tiap indikator.Tiap indikator ini menunjukkan hasil tes tentang kemampuan analogi responden.

Berdasarkan penelitian diperoleh hasil tes responden terhadap kemampuan analogi responden berkategori baik dengan rata-rata prosentase tes sebesar $69,52 \%$. Besarnya prosentase hasil tes kemampuan analogi responden dipengaruhi oleh beberapa faktor yang ada di dalam indikator-indikator .Faktor-faktor tersebut yang membuat prosentase hasil tes kemampuan analogi responden berada pada kategori baik.

Setelah penulis melakukan penelitian mengenai pengaruh penerapan mathematics movie terhadap minat belajar matematikadan kemampuan analogi responden didapat data minat belajar matematika dan kemampuan analogi responden yang diperoleh dari kelas eksperimen. Data tersebut kemudian diolah dan dianalisis dengan menggunakan program SPSS versi 19,0. Penelitian ini menggunakan metode eksperimen, dimana penulis terlibat langsung dalam proses belajar mengajar dengan menggunakan mathematics movie pada kelas eksperimen. Penulis menggunakan mathematics movie dalam pembelajaran untuk mengukur minat belajar matematika melalui pemberian angket dan kemampuan analogi responden melalui tes dengan mengambil nilai dari post tes. Pembelajaran 
dengan menggunakan mathematics movie memberikan pengalaman baru bagi para responden dan membuat pembelajaran menjadi efektif dan lebih bermakna.

Berdasarkan hasil analisis data skala sikap dapat disimpulkan bahwa secara keseluruhan sikap responden terhadap penggunaan mathematics movie dapat memotivasi responden dan meningkatkan minat belajar.Selain itu, dari hasil analisis data skala sikap dapat disimpulkan bahwa secara keseluruhan sikap responden terhadap penggunaan mathematics movie menunjukkan sikap positif/baik. Hal ini terbukti bahwa sebesar 71,6 \% yang memberikan respon positif terhadap penerapan mathematics movie.

Berdasarkan hasil analisis data maka untuk mengetahui kemampuan analogi responden dapat dilihat dari hasil tes kemampuan analogi. Hal ini ditunjukkan dengan rata-rata nilai yang diperoleh responden kelas eksperimen sebasar 68 setelah diterapkan pembelajaran dengan mathematics movie pada proses belajar mengajar. Hasil tes kemampuan analogi responden pada kelompok eksperimen telah mencapai skor sebesar $55 \%$ dari skor ideal dan termasuk dalam kategori baik dan telah mencapai criteria ketuntasan minimal (KKM) yang telah ditetapka yaitu 70 .

Hasil data analisis diketahui bahwa terdapat pengaruh yang signifikan antara mathematics movie terhadap minat belajar matematika, dari hasil analisis regresi gandauntuk kelas eksperimen memiliki nilai koefisien determinasi R 2 (R Square) sebesar 0,33 atau (33\%) variabel dependen minat belajar matematika dan 0,206 atau 20,6 \% variabel kemampuan analogi responden dijelaskan oleh variabel independent penerapan mathematics movie dan, sisanya dijelaskan oleh variabel lain diluar variabel yang digunakan.

Terdapat pengaruh yang signifikan antara minat belajar matematika terhadap kemampuan analogi responden. Nilai koefisien determinasi R2 ( $R$ Square) sebesar 0,25 atau ( $25 \%$ ) variabel dependen minat belajar matematika dan kemampuan analogi responden dijelaskan oleh variabel independent penerapan mathematics movie dan, sisanya dijelaskan oleh variabel lain diluar variabel yang digunakan. Hal ini, dapat diketahui setelah penulis memperoleh data hasil dari penelitian di lapangan dan pengolahan data yang telah dilakukan, maka 
didapatkan hasil perhitungan statistik.Hasil uji statistik menunjukkan bahwa ada hubungan antara mathematics movie terhadap minat belajar matematika dan kemampuan analogi responden yaitu korelasi positif, yaitu apabila nilai mathematics movie mengalami peningkatan, maka minat belajar matematika dan kemampuan analogi responden pun mengalami peningkatan.

Dengan kata lain, semakin tinggi nilai mathematics movie semakin tinggi nilai minat belajar matematika dan kemampuan analogi. Dari beberapa penjelasan di atas, penulis dapat menarik kesimpulan bahwa terdapat pengaruh secara signifikan dalam penerapan mathematics movie terhadap minat belajar matematika dan kemampuan analogi responden.

\section{SIMPULAN}

Berdasarkan hasil analisis data yang diperoleh dari postes menggunakan pembelajaran mathematics movie.Penelitian ini menggunakan instrumen pengumpulan data berupa angket dan tes pilihan ganda. Berdasarkan hasil penelitian yang dilakukan, dapat disimpulkan sebagai berikut:

1. Respon responden terhadap pembelajaran matematika dengan menggunakan mathematics movie berkategori baik dengan rata-rata prosentase angket sebesar 71,3\%. Besarnya respon responden terhadap pembelajaran matematika yang mengunakan mathematics movie dipengaruhi oleh beberapa faktor, antara lain dapat menambah pengalaman belajar, sesuai dengan pokok bahasan yang diajarkan, dapat memperjelas materi yang diajarkan. Faktorfaktor tersebut yang membuat respon responden terhadap penerapan mathematics movie berada pada kategori baik.

2. Minat belajar matematika responden setelah diterapkan mathematics movie tergolong tinggi atau meningkat. Ini berarti hipotesis alternative diterima, Oleh karena nilai $\mathrm{t}$ hitung $>\mathrm{t}$ tabel $(4,011>2,036933)$ dengan nilai signifikansi $0,000<0,05$, maka Ho ditolak dan Ha diterima, artinya ada pengaruh positif mathematics movie terhadap minat belajar matematika. Atau dengan kata lain variabel mathematics movie berpengaruh secara individual dan signifikan terhadap minat belajar matematika. Hasil analisis menunjukkan 
bahwa penerapan mathematics movie berpengaruh positif terhadap minat belajar matematika sebesar $33 \%$ sisanya $67 \%$ disebabkan oleh variabel atau faktor lain yang tidak diteliti dalam penelitian ini.

3. Kemampuan analogi responden setelah diterapkan mathematics movie tergolong tinggi atau meningkat. Ini berarti hipotesis alternative diterima, Oleh karena nilai $\mathrm{t}$ hitung $>\mathrm{t}$ tabel $(2,930>2,03452)$, dengan tingkat signifikansi 0,006 < 0,05 maka Ho ditolak dan Ha diterima, artinya terbukti akan kebenarannya, ada pengaruh positif mathematics movie terhadap kemampuan analogi responden. Atau dengan kata lain variabel mathematics movie 125 berpengaruh secara individual dan signifikan terhadap kemampuan analogi responden. Pengaruh mathematics movie terhadap kemampuan analogi responden sebesar 20,6\%, sisanya 79,4\% terbentuknya kemampuan analogi responden tersebut disebabkan oleh variabel atau faktor lain yang tidak diteliti dalam penelitian ini.

4. Minat belajar matematika dapat mempengaruhi kemampuan analogi responden, berdasartkan hipotesis alternative diterima, Oleh karena nilai $\mathrm{t}$ hitung > t tabel $(3,316>2,03452)$, dengan tingkat signifikansi 0,002 $<0,05$ maka Ho ditolak dan Ha diterima, artinya terbukti akan kebenarannya, ada pengaruh positif minat belajar matematika terhadap kemampuan analogi responden. Atau dengan kata lain variabel minat belajar matemtika berpengaruh secara individual dan signifikan terhadap kemampuan analogi responden. Pengaruh minat belajar matematika terhadap kemampuan analogi responden sebesar $25 \%$, sisanya $75 \%$ disebabkan oleh variabel atau faktor lain yang tidak diteliti dalam penelitian ini. 


\section{DAFTAR PUSTAKA}

Arifin, Zaenal. 2009. Evaluasi Pembelajaran. Bandung: PT Remaja Rosdakarya

Arry S, dkk. 2008. Matematika SMK Bisnis Dan Manajemen. Jakarta: Direktorat Pembinaan Sekolah Menengah Kejuruan.

Arsyad, azhar. 2003. Media Pembelajaran. Jakarta: Raja Grafindo Persada.

Azhar, Arsyad. 2003. Media Pembelajaran. Jakarta: PT Raja Grafindo Persada.

Daryanto. 2010. Belajar dan Mengajar, Bandung: Yrama Widya

Fauzi, Ahmad. 2004. Psikologi Umum. Bandung: CV Pustaka Setia

Hamdani. 2011. Strategi Belajar Mengajar. Bandung: Pustaka Setia.

Herman Hudoyono. 1998. Mengajar Belajar Matematika. Dirjen Dikti. Jakarta: P2LPTK

Husaini, Purnomo Usman. 2007. Pengantar Statistik. Jakarta: Bumi Aksara

Kementrian Pendidikan dan Kebudayaan RI. 2013. Matematika untuk SMA kelas X. Jakarta: Kementrian Pendidikan dan Kebudayaan

Muhsetyo, G. dkk. (2008). Pembelajaran Matematika SD. Jakarta: Universitas Terbuka.

Nasution, Zulkarimein. Media Dalam Pembelajaran. Jakarta: CV. Rajawali, 1984

Reys, R. E.. (1998). Helping Children Learn Mathematics,edisi 5. USA: A Viacom Company.

Riduwan. 2008. Dasar-Dasar Statistik. Bandung: Alfabeta

Sadiman, A. dkk. (2009). Media Pendidikan, Jakarta: Pustekom Dik.Bud dan CV. Rajawali.

Smith, N. L. (1988). Helping Children Learn Mathematics. Needham Height: A Viacom Company.

Sudjana, N. \& Rivai, A. (2009).Media Pengajaran.Bandung: Sinar Baru Algesindo.

Sugiyono. 2008. Metode Penelitian Pendidikan Pendekatan Kuantitatif, Kualitatif dan R \& D. Bandung: Alfabeta

Suharsimi Arikunto. 1998. Prosedur Penelitian Suatu Pendekatan Praktek. Jakarta: Rineka Cipta 